Das et al., 2009

\section{Antidiabetic Action of Ethanolic Extracts of Punica granatum Linn. in Alloxan-induced Diabetic Albino Rats}

Swarnamoni Das ${ }^{1}$, Gayatri Sarma ${ }^{1^{*}}$

Department of Pharmacology ${ }^{1}$

Assam Medical College and Hospital,

Dibrugarh-786002, Assam, India.

\author{
*Corresponding Author \\ Gayatri Sarma \\ Final year Post graduate student \\ Department of Pharmacology \\ Assam Medical College and Hospital \\ Contact no.: +919435043164 \\ E-mail: gayatrisarma2008@yahoo.com
}

Received-20 January, 2009 Accepted for Publication-10 April, 2009

\begin{abstract}
Antidiabetic action of ethanolic extracts of seed and rind of Punica granatum L. was evaluated on alloxaninduced diabetic albino rats. Both the extracts, each at a dose of $200 \mathrm{mg} / \mathrm{kg} / \mathrm{d}$, were administered orally for two weeks to alloxan-induced diabetic rats. Blood glucose was estimated every week for two consecutive weeks. For evaluation of probable mechanism of action of the extracts, glycogen estimation was carried out in liver, heart and skeletal muscle and effect on adrenaline-induced hyperglycemia was observed. Both the extracts significantly $(p<0.05)$ reduced the rise in blood glucose induced by alloxan, with the rind extract exhibiting significantly $(p<0.05)$ better activity than seed extract. Both the extracts also produced significant $(p<0.05)$ increase in liver glycogen and significantly $(p<0.05)$ reduced adrenaline-induced hyperglycemia. These results support strong antidiabetic action in favor of $P$. granatum seed and rind extracts
\end{abstract}

Key words: Punica granatum L., Ethanolic extracts, Antidiabetic, Alloxan.

\title{
INTRODUCTION
}

Punica granatum L. (Family-Punicaceae), commonly known in India as 'Anar' or 'Dalim', is a highly ornamental large deciduous shrub or small tree widely distributed and cultivated in many parts of India. The rind of the fruit is anthelmintic and is useful in diarrhoea and dysentery. The seeds are used in scabies, liver and kidney disorders (Kirtikar and Basu, 1988). Phytochemical analysis of the seeds have revealed the presence of ursolic acid, $\beta$-sitosterol, estrogens and phenolic glycosides (Ahmed et al., 1995) while the rind has been reported to contain tannins (ellagitannins- punicalagin), flavonoids and colouring matters (Evans, 2002). Biological testing of the various extracts of the leaves, seeds roots and stem barks revealed their hypotensive, antispasmodic and anthelmintic effects (Sharaf et al., 1967). Antibacterial effect of $P$. granatum leaves (Nair and Chanda, 2005) and hypoglycemic action of flowers (Huang et al., 2005), seeds (Das et al., 2001) and rind (Khalil et al., 2004) have been reported. Literature reviews indicated that no studies showing comparison on the antidiabetic potential of the rind and seed of this plant on alloxan-induced diabetes have so far been undertaken. In this backdrop, the present study was aimed to compare the antidiabetic activity of ethanolic extracts of seed and rind of $P$. granatum in alloxan-induced diabetic albino rats and also to examine the probable mechanism underlying the antidiabetic action of the extracts.

\section{EXPERIMENTAL}

\section{Plant material}

The fruits of $P$. granatum were collected from the local market in Dibrugarh in the months of June to August. The plant material was authenticated by Dr. L.R. Saikia, Reader, Department of Life Sciences, Dibrugarh University, Dibrugarh. A voucher specimen (No. DU/LS/211) was deposited at the Department of Life Sciences, Dibrugarh University, Dibrugarh.

\section{Extraction}

The seeds and rinds of $P$. granatum were manually separated from the whole fruits, air dried, and powdered (1200 g each of seed and rind powder). Ethanolic extracts were prepared using $90 \%$ 
ethanol by percolation method (Nairn JG, 2000). The extracts were evaporated to dryness under vacuum and dried in vacuum desiccators to obtain a final yield of $257.5 \mathrm{~g}$ of the seed extract $(21.5 \% \mathrm{w} / \mathrm{w})$ and $188 \mathrm{~g}$ of the rind extract $(15.7 \% \mathrm{w} / \mathrm{w})$.

\begin{abstract}
Animals
The study was carried out in healthy adult albino rats (Rattus norvegicus) of either sex (100-200 g each). Rats were housed in clean polypropylene cages with food pellets and tap water provided ad libitum. Permission from the Institutional Animal Ethical Committee for laboratory use of animals (Registration no: 634/02/a/CPCSEA; dated 19/05/2002) was duly obtained and the animals were taken care of as per the guidelines of the Committee for the Purpose of Control and Supervision of Experiments on Animals (CPCSEA).
\end{abstract}

\title{
Acute Toxicity Study
}

Acute oral toxicity test for the ethanolic extract of seed of $P$. granatum (EESP) and ethanolic extract of rind of $P$. granatum (EERP) was carried out as per OECD Guidelines 425 (OECD, 2006).

\section{Chemicals Used}

Crude powder of glibenclamide was obtained from Aventis Pharma Ltd., Goa while alloxan monohydrate was purchased from Sigma Aldrich India, Bangalore. The glucose kit for blood glucose estimation was obtained from Sigma Diagnostic (India) Pvt. Ltd., Baroda.

\section{Experimental Design for Antidiabetic Study:}

The study was done as described by Akhtar et al., (2007). A total of thirty-six animals were equally divided into five groups with six animals in each group:
Group-A
Group-B
Normal Control. Received normal saline, $10 \mathrm{ml} / \mathrm{kg} / \mathrm{d}$.
Group-C
Diabetic Control. Received normal saline, $10 \mathrm{ml} / \mathrm{kg} / \mathrm{d}$.
Group-D
Diabetic Test. Received EESP, $200 \mathrm{mg} / \mathrm{kg} / \mathrm{d}$.
Group-E
Diabetic Test. Received EERP, $200 \mathrm{mg} / \mathrm{kg} / \mathrm{d}$.
Diabetic Standard. Received glibenclamide, $0.5 \mathrm{mg} / \mathrm{kg} / \mathrm{d}$ (Ghosh, 2005a).

The above drugs were administered orally, once daily, for two weeks.

\section{Induction of Diabetes}

Leaving aside six rats for Normal Control Group, 30 rats were induced diabetes by a single intraperitoneal injection of alloxan monohydrate in the dose of $150 \mathrm{mg} / \mathrm{kg}$ body weight. The fasting blood glucose was determined after 72 hours. Only 24 rats showing blood glucose level greater than $200 \mathrm{mg} / 100 \mathrm{ml}$ were taken for the study (Prajapati et al., 2008). Blood glucose was estimated every week for two consecutive weeks. Blood samples were collected from the orbital sinus of rats (Ghosh, 2005b) and glucose estimation was done by glucose oxidase method (McLauchlan, 1988).

\section{Probable Mechanism of Antidiabetic Action}

1. Glycogen Estimation of Liver, Skeletal Muscle and Cardiac Muscle: The study was carried out as per the method of Carroll et al., (1956). Out of 36 rats, 30 rats were induced diabetes by alloxan monohydrate $(150 \mathrm{mg} / \mathrm{kg}$ body weight) intraperitoneally and 24 rats with blood glucose level greater than $200 \mathrm{mg} / 100 \mathrm{ml}$ were taken after 72 hours of diabetes induction. All the rats were kept fasting for 18 hours before the experiment. The rats were divided into five groups with six animals in each, as before.

Group-A : Normal Control. Received normal saline, $10 \mathrm{ml} / \mathrm{kg} / \mathrm{d}$.

Group-B : DiabeticControl. Received normal saline, $10 \mathrm{ml} / \mathrm{kg} / \mathrm{d}$ and alloxan.

Group-C : Diabetic Test. Received EESP, $200 \mathrm{mg} / \mathrm{kg} / \mathrm{d}$ and alloxan.

Group-D : Diabetic Test. Received EERP, $200 \mathrm{mg} / \mathrm{kg} / \mathrm{d}$ and alloxan

Group-E : Diabetic Standard. Received glibenclamide, $0.5 \mathrm{mg} / \mathrm{kg} / \mathrm{d}$ and alloxan.

After two hours of administration of above drugs. The animals were killed by decapitation. The liver, leg muscle and heart tissues were taken out with care and their glycogen content was estimated by use of Anthrone reagent. 
2. Effect on Adrenaline-induced Hyperglycemia :

The method described by Anturlikar et al., (1995) was adopted to study the effect on adrenalineinduced hyperglycemia. The rats were divided into four groups with six animals in each as before.
Group-A
: Normal Control. Received normal saline, $10 \mathrm{ml} / \mathrm{kg} / \mathrm{d}$
Group-B
Test Drug. Received EESP, $200 \mathrm{mg} / \mathrm{kg} / \mathrm{d}$
Group-C
Test Drug. Received EERP, $200 \mathrm{mg} / \mathrm{kg} / \mathrm{d}$
Group-D : Standard Drug. Received glibenclamide, $0.5 \mathrm{mg} / \mathrm{kg} / \mathrm{d}$

The above drugs were administered orally after drawing fasting blood samples. Adrenaline hydrochloride $100 \mu \mathrm{g}$ was administered intraperitoneally to all the rats one hour after drug administration. Blood samples were again collected half an hour later.

\section{Statistical Analysis}

The data was statistically analysed using One-way ANOVA followed by Dunnett's multiple comparison test and Bonferroni (Chiplonkar, 1996). The statistical analysis was done using computerised GraphPad Prism software version 5.00. Values of $p<0.05$ were considered significant.

\section{RESULTS}

\section{Acute toxicity tests}

There was no mortality recorded among the rats up to the maximum dose of $2000 \mathrm{mg} / \mathrm{kg}$. Hence, the $L D_{50}$ of both the extracts can be said to be above $2000 \mathrm{mg} / \mathrm{kg}$. One-tenth of the maximum dose tested was selected for the experiments (Koneri and Balaraman, 2008).

Table-1: Effects of EESP and EERP on blood glucose level of alloxan-induced diabetic rats

\begin{tabular}{|c|c|c|c|c|}
\hline \multicolumn{5}{|c|}{ Mean Blood Glucose Level in mg/100ml } \\
\hline Groups & $\begin{array}{c}\text { ‘0 Day’ } \\
\text { (Base line ) }\end{array}$ & $\begin{array}{c}\text { '1 } 1^{\text {st day' }} \\
\text { (After } \\
72 \text { Hours) }\end{array}$ & '8 $8^{\text {th }}$ Day' & ' $15^{\text {th }}$ Day' \\
\hline $\begin{array}{l}\text { Normal Control } \\
\text { (Normal Saline; } \\
10 \mathrm{ml} / \mathrm{kg} / \mathrm{d}) \text { ) }\end{array}$ & $89 \pm 1.00$ & $112 \pm 0.93$ & $109 \pm 1.34$ & $111 \pm 0.86$ \\
\hline $\begin{array}{l}\text { Diabetic Control } \\
\text { (Alloxan + Normal } \\
\text { saline; } 10 \mathrm{ml} / \mathrm{kg} / \mathrm{d} \text { ) }\end{array}$ & $90 \pm 1.34$ & $296 \pm 2.32^{a}$ & $330 \pm 1.00^{\mathrm{a}}$ & $372 \pm 1.34^{a}$ \\
\hline $\begin{array}{l}\text { Diabetic Test } \\
\text { (Alloxan + EESP; } \\
200 \mathrm{mg} / \mathrm{kg} / \mathrm{d} \text { ) }\end{array}$ & $88 \pm 1.53$ & $310 \pm 0.68^{a}$ & $235 \pm 2.27^{\mathrm{b}, \mathrm{c}, \mathrm{d}}$ & $151 \pm 1.77^{\mathrm{b}, \mathrm{c}, \mathrm{c}}$ \\
\hline $\begin{array}{l}\text { Diabetic Test } \\
\text { ( Alloxan +EERP; } \\
200 \mathrm{mg} / \mathrm{kg} / \mathrm{d} \text { ) }\end{array}$ & $89 \pm 2.28$ & $300 \pm 1.98^{a}$ & $196 \pm 1.55^{\mathrm{b}, \mathrm{e}}$ & $139 \pm 1.16^{\mathrm{b}, \mathrm{e}}$ \\
\hline $\begin{array}{l}\text { Diabetic Standard } \\
\text { (Alloxan + } \\
\text { Glibenclamide; } \\
0.5 \mathrm{mg} / \mathrm{kg} / \mathrm{d} \text { ) }\end{array}$ & $92 \pm 1.21$ & $279 \pm 1.07^{\mathrm{a}}$ & $184 \pm 0.77^{b}$ & $127 \pm 1.48^{b}$ \\
\hline \multirow{3}{*}{ ANOVA } & 0.9746 & 2930 & 2983 & 6380 \\
\hline & 4,25 & 4,25 & 4,25 & 4,25 \\
\hline & $>0.05$ & $<0.05$ & $<0.05$ & $<0.05$ \\
\hline
\end{tabular}

Values are expressed as Mean \pm SEM; $n=6$ rats in each group. One-way ANOVA followed by Dunnett's multiple comparison test and Bonferroni was done. ${ }^{a} p<0.05$ when compared to Normal Control Group. ${ }^{b} p<0.05$ when compared to Diabetic Control Group. ${ }^{c} p<0.05$ when compared to Diabetic Test (EERP) Group. ${ }^{d} p<0.05$ and ${ }^{\mathrm{e}} \mathrm{p}<0.05$ when compared to Diabetic Standard Group. 


\section{Effect on fasting blood glucose level of diabetic rats}

On repeated administration of the extracts and glibenclamide for two weeks, a significant $(p<$ 0.05) decrease in blood glucose was found in EESP administered Group, EERP administered Group and Diabetic Standard Group respectively as compared to Diabetic Control Group which showed a significant $(p<0.05)$ rise in blood glucose as compared to Normal Control Group. The bood glucose lowering activity of EERP was significantly $(p<0.05)$ more as compared to that of EESP. However, among the three administered drugs i.e EESP, EERP and glibenclamide, the greatest blood glucose lowering action was exhibited by glibenclamide (Table-1).

\section{Effect on Glycogen Estimation}

There was a significant $(p<0.05)$ increase in the glycogen content of liver, skeletal muscle and cardiac muscle in EESP administered Group, EERP administered Group and Diabetic Standard Group respectively as compared to Diabetic Control Group which showed a significant $(p<0.05)$ reduction in glycogen content in the above tissues as compared to Normal Control Group. However, the increase in glycogen content in these tissues caused by EERP was significantly $(p<$ 0.05 ) more than that by EESP (Table-2).

Table-2: Effect on glycogen concentration in liver, skeletal muscle and cardiac muscle

\begin{tabular}{|c|c|c|c|}
\hline \multirow{2}{*}{ Groups } & \multicolumn{3}{|c|}{ Glycogen Concentration (mg/100 g) } \\
\hline & Liver & Skeletal Muscle & Cardiac Muscle \\
\hline $\begin{array}{l}\text { Normal Control } \\
\text { ( Normal saline; } \\
10 \mathrm{ml} / \mathrm{kg} \text { ) }\end{array}$ & $45 \pm 1.00$ & $38 \pm 0.68$ & $32 \pm 0.89$ \\
\hline $\begin{array}{l}\text { Diabetic Control } \\
\text { (Alloxan + Normal } \\
\text { saline; } 10 \mathrm{ml} / \mathrm{kg} \text { ) }\end{array}$ & $6 \pm 1.07^{\mathrm{a}}$ & $5 \pm 0.93^{\mathrm{a}}$ & $3 \pm 0.58^{\mathrm{a}}$ \\
\hline $\begin{array}{l}\text { Diabetic Test } \\
\text { (Alloxan + EESP; } \\
\text { 200mg/kg) }\end{array}$ & $31 \pm 0.93^{b, c}$ & $20 \pm 1.67^{b, c, d}$ & $12 \pm 1.69^{b, c, d}$ \\
\hline $\begin{array}{l}\text { Diabetic Test } \\
\text { (Alloxan + EERP; } \\
\text { 200mg/kg) }\end{array}$ & $39 \pm 1.61^{b}$ & $28 \pm 1.95^{\mathrm{b}, \mathrm{e}}$ & $21 \pm 1.71^{\mathrm{b}, \mathrm{e}}$ \\
\hline $\begin{array}{l}\text { Diabetic Standard } \\
\text { (Alloxan + } \\
\text { Glibenclamide; } \\
0.5 \mathrm{mg} / \mathrm{kg} \text { ) }\end{array}$ & $48 \pm 1.86^{b}$ & $37 \pm 2.21^{b}$ & $30 \pm 1.39^{b}$ \\
\hline \multirow{3}{*}{ ANOVA } & 156.5 & 72.77 & 84.19 \\
\hline & 4,25 & 4,25 & 4,25 \\
\hline & $<0.05$ & $<0.05$ & $<0.05$ \\
\hline
\end{tabular}

Values are expressed as Mean \pm SEM; $n=6$ rats in each group. One-way ANOVA followed by Dunnett's multiple comparison test and Bonferroni was done. ${ }^{a} p<0.05$ when compared to Normal Control Group. ${ }^{b} p<0.05$ when compared to Diabetic Control Group. ${ }^{c} p<0.05$ when compared to Diabetic Test (EERP) Group. ${ }^{d} p<0.05$ and ${ }^{e} p<0.05$ when compared to Diabetic Standard Group.

\section{Effect on Adrenaline-induced Hyperglycemia}

Both test drugs and the standard drug significantly $(p<0.05)$ reduced hyperglycemia induced by adrenaline, with the reduction caused by EERP being significantly $(p<0.05)$ more than that by EESP. However, the maximum reduction of adrenaline-induced hyperglycemia was brought about by glibenclamide (Table-3 and Figure 1) 
Das et al., 2009

Table-3: Effect on adrenaline-induced hyperglycemia in albino rats

\begin{tabular}{|c|c|c|c|c|c|}
\hline \multirow[b]{2}{*}{ Groups } & \multicolumn{5}{|c|}{ Blood Glucose Level (mg/100 ml) } \\
\hline & $\begin{array}{l}\text { '0 hour' } \\
\text { Fasting }\end{array}$ & $\begin{array}{l}1 / 2 \text { hour after } \\
\text { Adrenaline }\end{array}$ & Change & $\%$ of Increase & $\begin{array}{c}\% \text { of } \\
\text { Decrease }\end{array}$ \\
\hline $\begin{array}{c}\text { Normal Control } \\
\text { (Normal saline; } \\
10 \mathrm{ml} / \mathrm{kg})\end{array}$ & $101 \pm 1.77$ & $193 \pm 2.11$ & $92 \pm 0.73$ & 91.09 & \\
\hline $\begin{array}{l}\text { Test Drug (EESP; } \\
200 \mathrm{mg} / \mathrm{kg})\end{array}$ & $104 \pm 1.86$ & $179 \pm 1.73^{a, b, c}$ & $75 \pm 1.07^{\mathrm{a}, \mathrm{b}, \mathrm{c}}$ & 72.12 & 20.83 \\
\hline $\begin{array}{l}\text { Test Drug (EERP; } \\
200 \mathrm{mg} / \mathrm{kg})\end{array}$ & $102 \pm 3.03$ & $158 \pm 2.32^{\mathrm{a}, \mathrm{d}}$ & $56 \pm 0.93^{a, d}$ & 54.90 & 39.73 \\
\hline $\begin{array}{c}\text { Standard Drug } \\
\text { (Glibenclamide; } \\
0.5 \mathrm{mg} / \mathrm{kg} \text { ) }\end{array}$ & $102 \pm 2.50$ & $148 \pm 1.16^{a}$ & $46 \pm 1.21^{a}$ & 45.10 & 50.49 \\
\hline \multirow{3}{*}{ ANOVA } & 0.2870 & 116.2 & 416.9 & & \\
\hline & 3,20 & 3,20 & 3,20 & & \\
\hline & $>0.05$ & $<0.05$ & $<0.05$ & & \\
\hline
\end{tabular}

Values are expressed as Mean $\pm \mathrm{SEM} ; \mathrm{n}=6$ rats in each group. One-way ANOVA followed by Dunnett's multiple comparison test and Bonferroni was done. ${ }^{a} p<0.05$ when compared to the Normal Control Group. ${ }^{b} p<0.05$ when compared to the Test Drug (EERP) Group. . ${ }^{c} p<0.05$ and ${ }^{d} p<0.05$ when compared to Diabetic Standard Group.

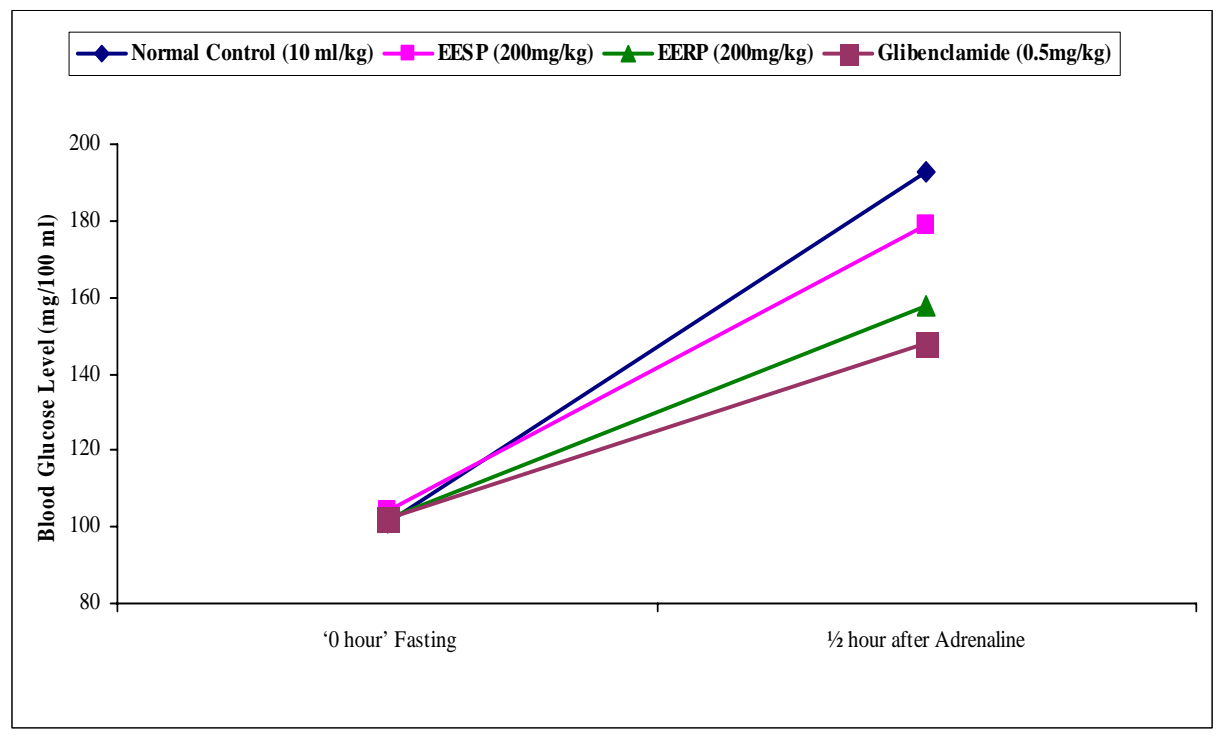

Figure 1: Effect on adrenaline-induced hyperglycemia in albino rats

\section{DISCUSSION}

The results found in the present study reflect that the ethanolic extracts of seed and rind of $P$. granatum possess significant $(p<0.05)$ antidiabetic action. The antidiabetic action of the seed and rind of $P$. granatum may be due to the insulin-like or insulin releasing action of the ingredients present in the seed and rind of the plant. The insulin-like and insulin releasing action of ingredients of many herbal plants have previously been reported (Bates et al., 2000; Gray et al., 1999). 
Alloxan, a $\beta$-cytotoxic agent, rapidly and selectively accumulates in pancreatic $\beta$-cells (Gorus et al., 1982) and causes $\beta$-cell death and apoptosis by generation of reactive oxygen species (ROS), superoxide radicals and hydrogen peroxide (Szkudelski, 2001). $\beta$ cell death causes hyperglycemia due to insulin deficiency which further aggravates the oxidative stress induced by alloxan (Kaneto et al., 1996).. The antidiabetic activity of the seed and rind of $P$. granatum might be attributed to the presence in them of tannins, flavonoids and phenolic glycosides, known to be natural antioxidants (Evans, 2002), which protect the existing $\beta$-cells (which escaped alloxanization) from dying by their free radical scavenzing action (Kaneto et al., 1999). The rind of $P$. granatum has been reported to possess the highest antioxidant activity among the peel, pulp and seed fractions of 28 kinds of fruits commonly consumed in China (Mohamed, 2007). Insulin is a potent activator of the enzyme glycogen synthase while inhibiting the enzyme glycogen phosphorylase responsible for glycogenolysis in liver and muscle (Bollen et al., 1998). Insulin deficiency in diabetes, as such, results in reduced concentrations of glycogen in liver and muscle. EESP and EERP caused an increase in glycogen concentration of the liver probably by stimulating the enzymes glycogen synthase and hexokinase, both of which contribute to increased glycogen synthesis. Kumar et al., (2006) have reported the glycogen synthase stimulating action of fruits of Terminalia chebula. The increase in liver glycogen may also have been brought about by inhibition of the enzyme glucose-6phosphatase leading to accumulation of glucose-6-phosphate, which allosterically inhibited the enzyme glycogen phosphorylase (Schaftingen et al., 2002). Diminished phosphatidylinositol 3-kinase (PI-3K) activation in diabetes as a result of insulin deficiency has been reported to be associated with impaired skeletal muscle glycogen synthase enzyme (Nikoulina et al., 2001). The EESP and EERP, due to the insulin-like action of their ingredients, probably increased PI-3K activation leading to stimulation of muscle glycogen synthase. The increased concentration of glycogen in skeletal and cardiac muscle also might be due to increased expression and translocation of GLUT-4 glucose transporters as a result of increased $\mathrm{PI}-3 \mathrm{~K}$ activation, leading to increased peripheral uptake of glucose (Davis, 2006). Adrenaline produces hyperglycemia by inhibiting insulin release; stimulating glycogenolysis in muscle and thus providing substrate in the form of lactate for hepatic gluconeogenesis; stimulating glucagon secretion; and stimulating ACTH secretion which, in turn, stimulates glucocorticoid secretion from the adrenal cortex (Kraus-Friedmann, 1984). It has also been reported that adrenaline produces hyperglycemia by increasing glucose uptake from both the large and small intestine (Alada et al., 2001). The test drugs significantly $(p<0.05)$ reduced the adrenaline-induced hyperglycemia probably by inhibiting adrenaline-induced stimulation of $\alpha_{2}$ receptors in $\beta$-cells of pancreas and thus promoting further insulin release (Tripathi, 2008). On comparing the antidiabetic action of the ethanolic extracts of seed and rind of $P$. granatum, it was found that the rind exhibited better activity than the seed extract. Among the three drugs, glibenclamide was found to possess the best antidiabetic action.

\section{CONCLUSION}

Thus, it can be concluded that both the seed and rind extracts of $P$. granatum possess significant antidiabetic action, with the rind extract exhibiting better activity than the seed extract. The antidiabetic effect of these extracts may be, partly, due to their positive effect on glycogen synthesis in liver, skeletal muscle and heart muscle, and partly, due to their stimulatory action on insulin release. Further studies on molecular level are required to determine the exact mechanism of antidiabetic action after isolation of active principles from the seed and rind extracts of $P$. granatum.

\section{REFERENCES}

Ahmed R, Ifzal SM, Saifuddin A, Nazeer MJ. (1995) Short communication: Studies on punica granatum-I isolation and identification of some constituents from the seeds of punica granatum. Pak J Pharm Sci. 8(1): 69-71. 
Akhtar MA, Rashid M, Wahed MI, Islam MR, Shaheen SM, Islam MA, Amran MS, Ahmed M. (2007) Comparison of long-term antihyperglycemic and hypolipidemic effects between Coccinia cordifolia (Linn.) and Catharanthus roseus (Linn.) in alloxaninduced diabetic rats. Res J of Med and Med Sci. 2(1): 29-34.

Alada AA, Fagbohun TD, Oyebola DO. (2001) Effect of adrenaline on glucose uptake by the canine large bowel. Afr J Biomed Res. 4: 123-126.

Anturlikar SD, Gopumadhavan S, Chauhan BL, Mitra SK. (1995) Effect of D-400, a herbal formulation, on blood sugar of normal and alloxan induced diabetic rats. Ind J of Physiol Pharmacol. 39(2): 95-100.

Bates SH, Jones RB, Bailey CJ. (2000) Insulin-like effect of pinitol. British Journal of Pharmacology. 130: 1944-1948.

Bollen M, Keppens S, Stalmans W. (1998) Specific features of glycogen metabolism in the liver. Biochem J. 336: 19-31.

Carroll NV, Longley RW, Roe JH. (1956) The determination of glycogen in liver and muscle by use of anthrone reagent. J Biol Chem. 220: 583-596.

Chiplonkar SA, Rao KV. (1996) Analysis of variance. In: Biostatistics: a manual of statistical methods for use in health, nutrition and anthropology, $1^{\text {st }}$ Ed., edited by Rao KV, p. 237-272, Jaypee Brothers Medical Publishers (P) Ltd., New Delhi.

Das AK, Mandal SC, Banerjee SK, Sinha S, Saha BP, Pal M. (2001) Studies on the hypoglycaemic activity of Punica granatum seed in streptozotocin induced diabetic rats. Phytother Res. 15(7): 628-629.

Davis SN. (2006) Insulin, oral hypoglycemic agents, and the pharmacology of the endocrine pancreas. In: Goodman and Gilman's the pharmacological basis of therapeutics, $11^{\text {th }}$ Ed., edited by Brunton LL, Lazo JS, Parker KL, p. 1613-1645, Mc Graw-Hill Medical Publishing Division, New York.

Evans WC. (2002) Trease and Evans pharmacognosy, $15^{\text {th }}$ Ed. pp. 214-252 Saunders, an imprint of Elsevier Limited, Philadelphia.

Ghosh MN. (2005a) Fundamentals of experimental pharmacology, $3^{\text {rd }}$ Ed. pp. 190-197 Hilton and Company, Kolkata.

Ghosh MN. (2005b) Fundamentals of experimental pharmacology, $3^{\text {rd }}$ Ed. pp. 15-18 Hilton and Company, Kolkata.

Gorus FK, Malaisse WJ, Pipeleers DG. (1982) Selective uptake of alloxan by pancreatic B-cells. Biochem J. 208: 513-515.

Gray AM, Flatt PR. (1999) Insulin-secreting activity of the traditional antidiabetic plant Viscum album (mistletoe). Journal of Endocrinology. 160: 409-414.

Huang TW, Peng G, Kota BP, Li GQ, Yamahara J, Roufogalis BD, Li Y. (2005) Anti-diabetic action of Punica granatum flower extract: activation of PPAR- $y$ and identification of an active component. Toxicology and Applied Pharmacology. 207(2): 160-169.

Kaneto H, Fujii J, Myint T, Miyazawa N, Islam KN, Kawasaki Y, Suzuki K, Nakamura M, Tatsumi H, Yamasaki Y, Taniguchi N. (1996) Reducing sugars trigger oxidative modification and apoptosis in pancreatic $\beta$-cells by provoking oxidative stress through the glycation reaction. Biochem J. 320: 855-863.

Kaneto $\mathrm{H}$, Kajimoto $\mathrm{Y}$, Miyagawa J, Matsuoka T, Fujitani $\mathrm{Y}$, Umayahara $\mathrm{Y}$, Hanafusa $\mathrm{T}$, Matsuzawa Y, Yamasaki Y, Hori M. (1999) Beneficial effects of antioxidants in 
diabetes: possible protection of pancreatic $\beta$-cells against glucose toxicity. Diabetes. 48: 2398-2406.

Khalil EM. (2004) Antidiabetic effect of an aqueous extract of pomegranate ( Punica granatum L.) peels in normal and alloxan diabetic rats. The Egyp J of Hosp Med. 16: 92 - 99.

Kirtikar KR, Basu BD. (1988) Indian medicinal plants, $2^{\text {nd }}$ Ed. pp. 839-902 International Book Distributors, Dehradun.

Koneri R, Balaraman R. (2008) Antidiabetic mechanisms of saponins of Momordica cymbalaria. Pharmacognosy Magazine. 4(15): 197-206.

Kraus-Friedmann N. (1984) Hormonal regulation of hepatic gluconeogenesis. Physiological Reviews. 64(1): 170-177.

Kumar GS, Arulselvan P, Kumar DS, Subramanian SP. (2006) Anti-diabetic activity of fruits of Terminalia chebula on streptozotocin induced diabetic rats. J of Health Sci. 52(3): 283-291.

McLauchlan DM. (1988) Glucose, other sugars and ketones. In: Varley's practical clinical biochemistry, $6^{\text {th }}$ Ed., edited by Gowenlock AH, McMurray JR, McLauchlan DM, p. 320-332, Heinemann Medical Books, London.

Mohamed EA. (2007) Influence of pomegranate (Punica granatum) peel extract on the stability of sunflower oil during deep-fat frying process. Electronic Journal of Food and Plants Chemistry. 2(1): 14-19.

Nair R, Chanda S. (2005) Antibacterial Activity of Punica granatum in different solvents. Indian J of Pharm Sci. 67(2): 239-243.

Nairn JG. (2000) Solutions, emulsions, suspensions and extracts. In: Remington: the science and practice of pharmacy, $20^{\text {th }}$ Ed., edited by Gennaro A, Marderosian AD, Hanson GR, Medwick T, Popovich NG, Schnaare RL, Schwartz JB, White HS, p. 721-752, Lippincott Williams and Wilkins, Philadelphia.

Nikoulina SE, Ciaraldi TP, Carter L, Mudaliar S, Park KS, Henry RR. (2001) Impaired muscle glycogen synthase in type 2 diabetes is associated with diminished phosphatidylinositol 3-kinase activation. The Journal of Clinical Endocrinology and Metabolism. 86(9): 4307-4314.

OECD. (2006) Section 4, health Effects: test no. 425: acute oral toxicity: up-and-down procedure. In: OECD Guidelines for Testing of Chemicals (monograph on the Internet, cited 2008 Sep 27), p. 1-27, OECD Publishing, France. Available from: http://www.oecdbookshop.org/oecd/index.asp?lang=en

Prajapati DD, Patel NM, Savadi RV, Akki KS, Mruthunjaya K. (2008) Alleviation of alloxan-induced diabetes and its complications in rats by Actinodaphne hookeri leaf extract. Bangladesh J of Pharmacol. 3: 102-106.

Schaftingen EV, Gerin I. (2002) The glucose-6-phosphatase system. Biochem J. 362: 513-532.

Sharaf A, Fayez ME, Negm SR. (1967) Pharmacological properties of punica granatum L. Plant Foods for Human Nutrition. 14(4): 331-336.

Szkudelski T. (2001) The mechanism of alloxan and streptozotocin action in B cells of the rat pancreas. Physiol Res. 50: 536-546.

Tripathi KD. (2008) Essentials of Medical Pharmacology. $5^{\text {th }}$ Ed. pp. 116-131 Jaypee Brothers Medical Publishers (P) Ltd., New Delhi. 